\title{
Analisa Hubungan Perubahan Muka Air Laut dan Perubahan Volume Es di Kutub Selatan dengan Menggunakan Satelit Altimetri (Studi Kasus: Laut Selatan Pulau Jawa Tahun 2011 - 2014)
}

\author{
Luqman Hakim dan Ira Mutiara Anjasmara \\ Jurusan Teknik Geomatika, Fakultas Teknik Sipil dan Perencanaan, Institut Teknologi Sepuluh \\ Nopember (ITS) \\ Jl. Arief Rahman Hakim, Surabaya 60111 Indonesia \\ e-mail:ira@geodesy.its.ac.id
}

\begin{abstract}
Abstrak-Salah satu dampak perubahan iklim adalah perubahan permukaan air laut yang diakibatkan oleh mencairnya lapisan es utama dunia yaitu Kutub Utara dan Kutub Selatan. Fenomena perubahan muka air laut ini direpresentasikan dengan perubahan MSL (mean sea level). Efek dari kenaikan muka air laut secara signifikan juga dirasakan oleh penduduk Indonesia yang mayoritas penduduknya berada di pesisir. Perubahan muka air laut dapat diamati menggunakan sistem satelit Altimetri. Salah satunya adalah misi satelit Altimetri Jason-2. Perubahan volume es juga dapat diamati dengan sistem satelit Altimetri yaitu melalui misi satelit Altimetri Cryosat. Dalam Penelitian ini, pemantauan perubahan muka air laut dilakukan pada perairan selatan Jawa dalam kurun waktu 4 tahun (2011-2014) dengan mengambil 3 titik pengamatan yaitu Perairan Cilacap, Sadeng dan Prigi. Sedangkan untuk wilayah pengamatan volume es dilakukan pada daerah Kutub Selatan (Antartika) pada waktu yang sama. Hasil pengolahan data menunjukkan tren perubahan muka laut di selatan pulau Jawa sebesar $\mathbf{- 3 . 2} \mathbf{~ m m} /$ tahun. Sedangkan untuk tren perubahan volume es di Kutub Selatan adalah sebesar $206.069 \mathrm{~km}^{3} /$ tahun. Hubungan antara nilai perubahan muka air laut dan perubahan volume es di Kutub Selatan memberikan nilai korelasi sebesar 0.04444. Nilai korelasi tersebut menunjukkan bahwa antara tren perubahan muka laut di Selatan Jawa dan perubahan volume es di Kutub Selatan mempunyai hubungan yang lemah.
\end{abstract}

Kata Kunci-Altimetri, Cryosat, Jason-2, Sea Level Change, Volume Es

\section{PENDAHULUAN}

S ALAH satu dampak perubahan iklim adalah perubahan permukaan air laut yang diakibatkan oleh perubahan lapisan es utama dunia yaitu Kutub Utara dan Kutub Selatan. Fenomena perubahan muka air laut ini direpresentasikan dengan perubahan nilai MSL. Dalam sebuah publikasi dari Intergovermental Panel on Climate Change (IPCC) diberikan estimasi kenaikan muka air laut sebesar 26 $59 \mathrm{~cm}$ dalam masa 100 tahun ke depan [1].

Perubahan permukaan air laut dalam waktu yang cukup lama dengan nilai perubahan yang tinggi memiliki potensi yang bersifat destruktif pada populasi manusia yang bermukim di dekat pantai. Hal ini diakibatkan oleh pemuaian air laut yang akan meningkatkan intensitas dan frekuensi banjir serta menggenangi wilayah daratan. Efek dari perubahan muka air laut ini secara signifikan juga dirasakan oleh penduduk Indonesia yang mayoritas penduduknya berada di pesisir [2].

Seiring dengan kemajuan teknologi perubahan muka air laut dapat diamati menggunakan satelit altimetri salah satunya adalah Satelit Altimetri Jason-2. Selain itu untuk perhitungan volume es juga dapat digunakan misi satelit Altimetri Cryosat. Untuk pengolahan data, berkembang pula software yang khusus digunakan untuk mengolah data satelit altimetri yaitu Basic Radar Altimetry Toolbox (BRAT).

Untuk melihat kecenderungan perubahan muka air laut dan hubungannya dengan mencairnya es di Kutub Selatan digunakan analisa korelasi. Tren perubahan muka air laut dan pencairan es dianalisa menggunakan metode regresi linear.

Dari penelitian ini didapatkan hasil berupa besar perubahan muka air laut di wilayah perairan Selatan Jawa dan perubahan volume es di Kutub Selatan. Hasil tersebut kemudian dianalisa sehingga didapatkan tren perubahannya dan hubungannya sehingga dapat dilakukan pemodelan dan analisa hubungan antara kedua data tersebut guna perkembangan wilayah di Pesisir Laut Selatan Jawa.

\section{METODOLOGI PENELITIAN}

\section{A. Lokasi Penelitian}

Lokasi penelitian ini adalah perairan selatan Pulau Jawa. Wilayah perairan selatan Pulau Jawa meliputi perairan Cilacap, Prigi dan Sadeng (Yogyakarta).Wilayah penelitian berada pada koordinat $6^{\circ} 53^{\prime} 42.55 " \mathrm{LS}-9^{\circ} 59^{\prime} 7.14^{\prime \prime} \mathrm{LS}$ dan $104^{\circ} 53^{\prime} 14.43$ "BT - 114²9'39.33" BT. Lokasi penelitian dapat dilihat pada Gambar 1.

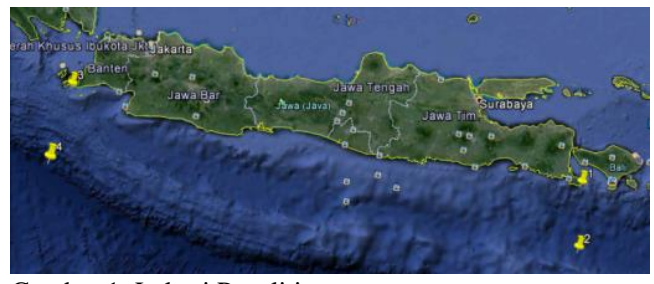

Gambar 1. Lokasi Penelitian. 


\section{B. Data yang Digunakan}

Data yang digunakan dalam tugas akhir ini adalah sebagai berikut.

1) Data dari satelit Altimetri Jason-2 format biner GDR (Geophysical Data Record) yang diproduksi oleh PODAAC dengan lama pengamatan 4 tahun 2011-2014.

2) Data dari satelit Altimetri Cryosat Low Rate Mode (LRM) dengan format GDR (Geophysical Data Record) yang diproduksi oleh PODAAC dengan lama pengamatan 4 tahun 2011 - 2014.

3) Data pasang surut dari Badan Informasi Geospasial (BIG) stasiun pengamatan Sadeng (Yogyakarta) dan dari stasiun pengamatan pasang surut global dari PSMSL (Permanent Service for Mean Sea Level) yaitu stasiun Cilacap, dan Prigi dalam periode tahun 2011 - 2014.

\section{Diagram Alir Pengolahan Data}

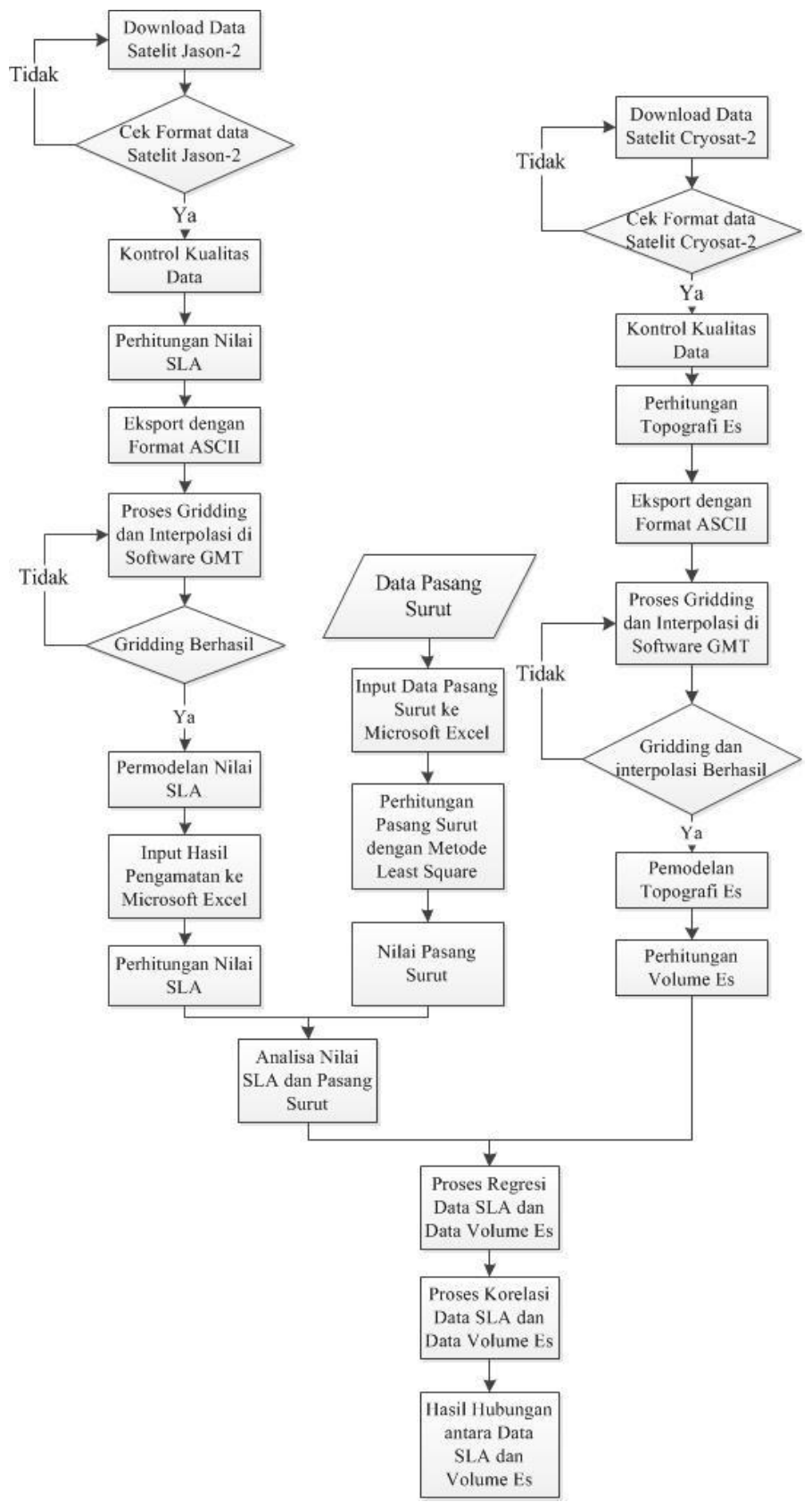

Gambar 2. Diagram Pengoahan Data
Tahapan pengolahan data berdasarkan gambar 2 adalah sebagai berikut :

1) Perhitungan SLA (Sea Level Anomaly)

Perhitungan nilai SLA, merupakan proses perhitungan tinggi permukaan laut dengan referensi geoid atau mean sea surface (MSS). Nilai SLA ini didapatkan dari nilai sea surface height (SSH) yang telah direferensikan terhadap geoid atau MSS dengan dihilangkan efek pasang surut dan pengaruh atmosfer. Dimana nilai SSH di dapat dari perhitungan tinggi permukaan laut dengan referensi dari elipsoid. SSH ditentukan dengan cara mengurangkan tinggi satelit dengan pengukuran altimeter yang telah dikoreksi. Pengukuran yang telah dikoreksi ini biasa disebut corrected range (p) [3]. Pengolahan pada tahap ini dilakukan dengan data perbulan dari satelit Jason -2.

Dalam proses perhitungan nilai rata-rata SLA, nilai SLA dari titik pengamatan, di perairan selatan Pulau Jawa dihitung, dimodelkan dan dianalisa dengan menggunakan regresi linear.

\section{2) Perhitungan Pasang Surut}

Dalam tahapan ini dilakukan pengolahan data dari data-data pasang surut dari 3 stasiun. Perhitungan pasang surut menggunakan metode least square yang merupakan metode perhitungan pasang surut dimana metode ini berusaha membuat garis yang mempunya jumlah selisih (jarak vertikal) antara data dengan regresi yang terkecil. Perhitungan pasang surut dengan metode least square merupakan proses perhitungan nilai pasang surut untuk mendapatkan komponenkomponen pasang surut sehingga didapatkan nilai pasang surut.

\section{3) Perhitungan Volume Es}

Perhitungan lapisan es (topografi es dan koefisien backscatter), merupakan proses perhitungan lapisan es yang bertujuan untuk mendapatkan nilai topografi dari permukaan es. Nilai parameter yang digunakan dalam perhitungan lapisan es adalah topo_dtul0 yang merupakan data yang memiliki resolusi tinggi $(20 \mathrm{HZ})$ dan sigO_ku yang merupakan data dengan resolusi tinggi $(20 \mathrm{~Hz})$. Untuk pembatasan area

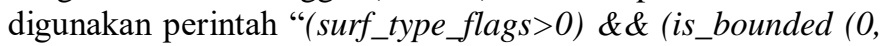
sigO_ku, 45))".

Kemudian dilakukan proses gridding dan interpolasi dengan metode Inverse Weight Distance dengan software GMT. Hasil akhir dari proses ini adalah pemodelan permukaan es perbulan untuk mengetahui nilai perubahan volume es.

Perhitungan volume di software GMT, dimana dalam proses ini dilakukan perhitungan volume dengan menggunakan permukaan hasil gridding setiap waktu untuk mengetahui nilai volume tersebut. Nilai volume, merupakan hasil dari perhitungan volume dari lapisan es.

4) Analisa Nilai SLA dan Pasang Surut

Kegiatan ini merupakan proses validasi nilai SLA dengan data pasang surut insitu di daerah pengamatan. Dimana pada proses ini dicari hubungan antar ke dua data dengan menggunakan proses korelasi.

5) Analisa Nilai SLA dengan Volume Pencairan Es

Pada tahap ini dihubungkan nilai pencairan es di Kutub Selatan dengan nilai SLA yang ada. Dari analisa ini akan dicari hubungan dengan memodelkannya dalam regresi linear. 6) Analisa Akhir

Untuk menyatakan hubungan antara data volume es dan kenaikan muka air laut menggunakan korelasi dan untuk 
menyajikan hasil perubahan nilai Sea Level Anomaly (anomali muka air laut) dan perubahan volume es di kutub dalam bentuk grafik.

\section{HASIL DAN ANALISA}

\section{A. Hasil Pengolahan SLA}

Langkah awal sebelum dilakukan pengolahan SLA adalah pengecekan data dengan menggunakan kontrol kualitas data yang mengacu pada parameter yang tercantum pada OSTM/Jason-2 Products Handbook [4]. Setelah dilakukan pengecekan data lalu dilanjutkan pengolahan SLA dengan menggunakan perangkat lunak BRAT dengan menggunakan parameter-parameter untuk pengolahan SLA. Kemudian dilakukan pengeplotan pada ruang views untuk mengetahui SLA dalam bentuk gambar.

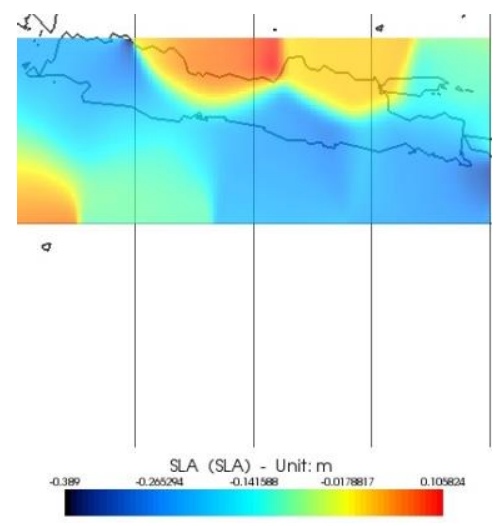

Gambar 3. SLA Bulan September 2011 Hasil Pengolahan Menggunakan BRAT

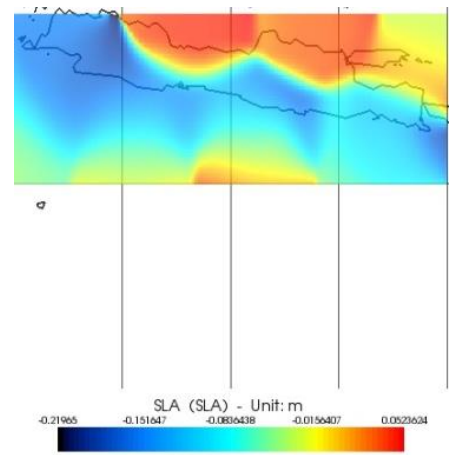

Gambar 4. SLA Bulan September 2012 Hasil Pengolahan Menggunakan BRAT

Setelah proses penghitungan SLA selesai. Kemudian dilakukan proses export data SLA pada perangkat lunak BRAT. Proses ini dilakukan untuk mengubah data dari format grid (.nc) menjadi format text (.txt).

Hasil dari format .txt dilakukan pengeplotan menggunakan software GMT untuk selanjutnya dilakukan proses gridding dan interpolasi. Sehingga menghasilkan model yang lebih baik.

\section{SLA September 2011}

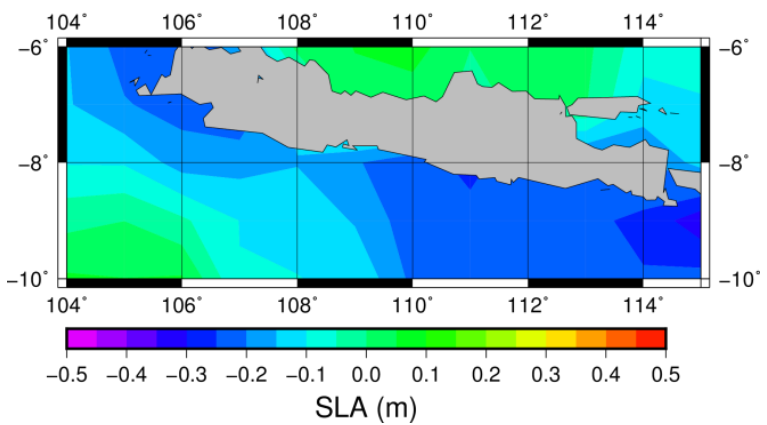

Gambar 5. Hasil Pemodelan SLA di Software GMT Bulan September 2011

Hasil nilai SLA dengan format text kemudian dicari koordinat titik sampel dan kemudian dimasukkan ke dalam Microsoft Excel untuk melakukan analisa nilai SLA pada setiap titik sampel pengamatan pada tahun 2011 - 2014. Kemudian dilakukan plotting nilai SLA dari koordinat titik sampel pada grafik untuk mengetahui tren perubahannya.

Tabel 1.

Lokasi Koordinat Titik Sampel Pengamatan dari Satelit Jason-2

\begin{tabular}{lccc}
\hline \hline Nama Stasiun & Lintang & Bujur & $\begin{array}{c}\text { Jarak dengan } \\
\text { Stasiun Pasut }\end{array}$ \\
\hline Cilacap & -7.8125 & 109.0000 & $6.965 \mathrm{Km}$ \\
Sadeng & -8.2500 & 110.8125 & $6.812 \mathrm{Km}$ \\
Prigi & $-8,3125$ & 111.7500 & $3.799 \mathrm{Km}$ \\
\hline \hline
\end{tabular}

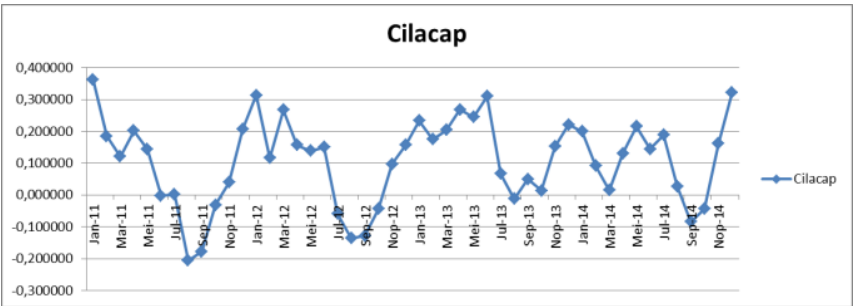

Gambar 6. Grafik SLA Perairan Cilacap Tahun 2011 - 2014

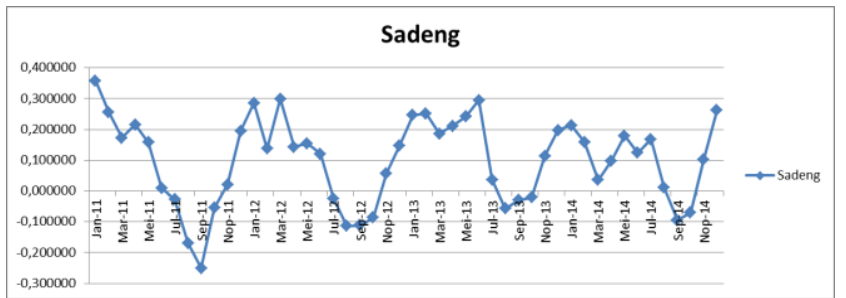

Gambar 7. Grafik SLA Perairan Sadeng Tahun 2011 - 2014

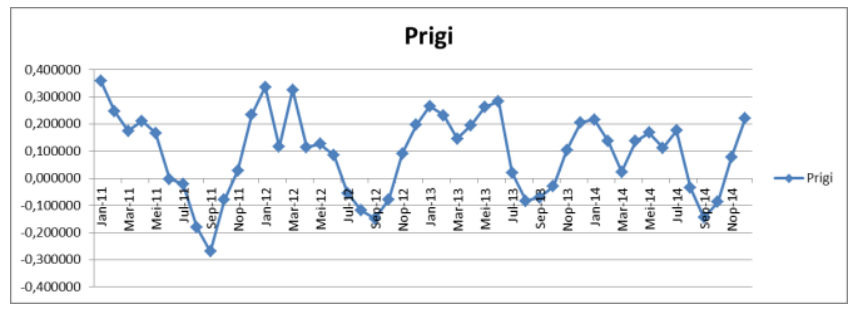

Gambar 8. Grafik SLA Perairan Prigi Tahun 2011 - 2014

Setelah itu dilakukan penghitungan SLA rata-rata pada setiap bulan untuk mengetahui nilai tertinggi dan terendah serta tren linear dari perairan selatan Jawa yang terjadi selama 4 tahun pengamatan. 


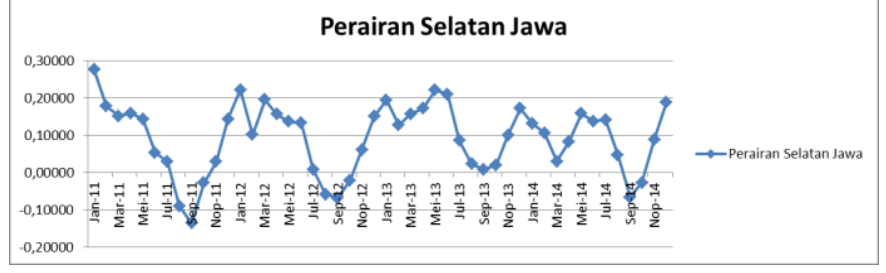

Gambar 9. Grafik SLA Perairan Selatan Jawa Tahun 2011 - 2014

Tabel 2.

SLA Tertinggi dan Terendah Setiap Tahun di Perairan Selatan Jawa.

\begin{tabular}{ccccc}
\hline \multirow{2}{*}{ Tahun } & \multicolumn{4}{c}{ SLA (meter) } \\
\cline { 2 - 5 } & Tertinggi & Bulan & Terendah & Bulan \\
\hline 2011 & 0,27611 & Januari & $-0,13596$ & September \\
2012 & 0,22191 & Januari & $-0,06877$ & September \\
2013 & 0,19443 & Januari & 0,00854 & September \\
2014 & 0,15882 & Mei & 0,00655 & September \\
\hline \hline
\end{tabular}

\section{B. Hasil Pengolahan Volume Es}

Untuk melakukan pengolahan volume es, lebih dauhulu dicari nilai topografi dari daerah kutub selatan. Dimana nilai topografi es didapatkan dari nilai koefisien topo_dtu10 pada dataset satelit Cryosat. Koefisien topo_dtulo merupakan, koefisien ketinggian bereferensi pada elipsoid. Nilai topografi didapatkan dengan pengolahan data satelit Cryosat setiap cycle. Kemudian memasukkan parameter sigO_ku untuk nilai sinyal untuk memisahkan karakteristik dari permukaan. Kemudian dilakukan pengeplotan pada ruang views untuk mengetahui topografi es dalam bentuk gambar.

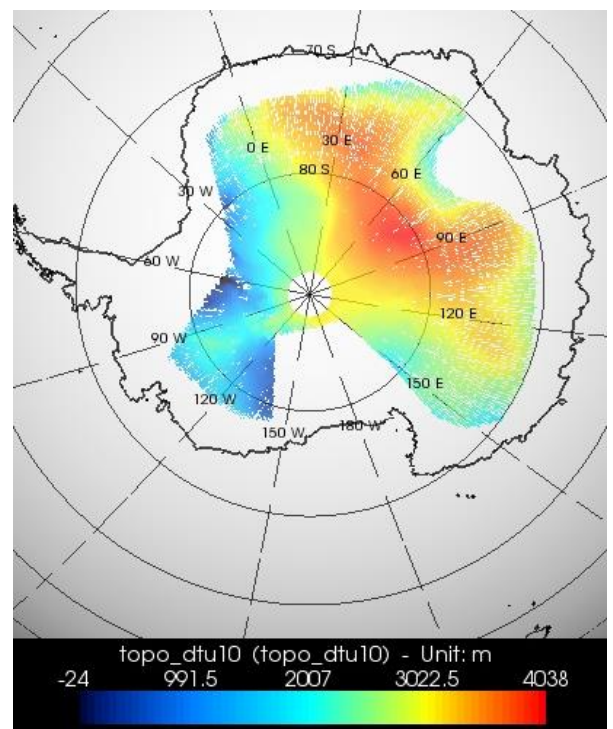

Gambar 10. Hasil Pengolahan Topografi Es Kutub Selatan Januari 2011

Setelah proses pengolahan topografi es selesai. Kemudian dilakukan proses export data pada perangkat lunak BRAT. Proses ini dilakukan untuk mengubah data dari format grid (.nc) menjadi format text (.txt).

Hasil dari format txt dilakukan pemodelan di software GMT untuk selanjutnya dilakukan proses gridding dan interpolasi. Sehingga menghasilkan model yang lebih baik. Kemudian dilakukan perhitungan volume es di software surfer untuk mendapatkan hasil volume es setiap bulannya.
Tabel 3

Volume Es Tertinggi dan Terendah Setiap Tahun Dari Kutub Selatan.

\begin{tabular}{ccccc}
\hline \hline \multirow{2}{*}{ Tahun } & \multicolumn{4}{c}{ Volume $\left(\mathrm{m}^{3}\right)$} \\
\cline { 2 - 5 } & Tertinggi & Bulan & Terendah & Bulan \\
\hline 2011 & 17747654 & Juli & 15432809 & Februari \\
2012 & 17835774 & April & 15226999 & Agustus \\
2013 & 18219640 & Desember & 14859009 & April \\
2014 & 18252379 & Oktober & 15774308 & Agustus \\
\hline \hline
\end{tabular}

\section{Hasil Pengolahan Nilai Pasang Surut}

Lokasi koordinat stasiun pasang surut ditunjukkan dalam tabel di bawah ini.

Tabel 4.

Lokasi Koordinat Stasiun Pasang Surut

\begin{tabular}{llc}
\hline \multicolumn{1}{c}{ Nama Stasiun } & \multicolumn{1}{c}{ Lintang } & Bujur \\
\hline Cilacap & $7^{0} 45^{\prime} 7,8^{\prime \prime}$ & $109^{0} 00^{\prime} 57,6^{\prime \prime}$ \\
Sadeng & $8^{0} 11^{\prime} 25,6^{\prime \prime}$ & $110^{0} 47^{\prime} 57,9^{\prime \prime}$ \\
Prigi & $8^{0} 17^{\prime} 12,7^{\prime \prime}$ & $111^{0} 43^{\prime} 39,3^{\prime \prime}$ \\
\hline \hline
\end{tabular}

Data yang didapat dari BIG maupun PSMSL [5] merupakan data pengamatan muka laut per jam. Sehingga untuk mendapatkan nilai muka air laut rata-rata (MSL) dilakukan dengan pengolahan metode least square. Berikut adalah hasil perhitungan nilai tertinggi dari tinggi muka air laut rata-rata dari 3 stasiun pengamatan tahun $2011-2014$.

Tabel 5.

Nilai Muka Air Laut Rata - Rata Tahun 2011 - 2014 (m)

\begin{tabular}{ccccc}
\hline \hline Nama & 2011 & 2012 & 2013 & 2014 \\
Stasiun & & & & \\
\hline Cilacap & 1,3461 & 1,3546 & 1,4420 & 1,3862 \\
Sadeng & 2,4867 & 3,1651 & 3,3456 & 3,2886 \\
Prigi & 1,3934 & 1,4167 & 1,4922 & 1,4353 \\
\hline \hline
\end{tabular}

\section{Analisa Nilai SLA dengan Nilai Pasang Surut}

Analisa hubungan data nilai SLA dengan nilai muka air laut rata-rata (pasang surut) menggunakan analisa korelasi. Dimana fungsi dari korelasi adalah untuk menentukan kuatnya atau dejarat hubungan linear antara dua variabel atau lebih [6]. Jika telah didapat nilai korelasi maka akan diketahui hubungan dari ke dua data tersebut. Berikut nilai korelasi SLA dengan muka air laut rata-rata selama tahun 2011 - 2014.

Tabel 6.

Nilai Korelasi Antara SLA dengan Mean Sea Level 2011 - 2014

\begin{tabular}{|c|c|c|c|c|c|c|}
\hline \multirow[b]{2}{*}{ Lokasi } & \multicolumn{2}{|c|}{ Koordinat Pasut } & \multicolumn{2}{|c|}{ Koordinat SLA } & \multirow{2}{*}{$\begin{array}{l}\text { Jarak } \\
(\mathrm{Km})\end{array}$} & \multirow[b]{2}{*}{ Korelas } \\
\hline & Long & Lat & Long & Lat & & \\
\hline Cilacap & $-7,752$ & 109,016 & $-7,812$ & 109,000 & 6,965 & 0,973 \\
\hline Sadeng & $-8,190$ & 110,799 & $-8,250$ & 110,812 & 6,812 & 0,517 \\
\hline Prigi & $-8,287$ & 111,728 & $-8,312$ & 111,750 & 3,799 & 0,983 \\
\hline
\end{tabular}

Dari nilai korelasi antara nilai SLA dan mean sea level dari pengamatan pasang surut, didapatkan nilai korelasi antara kedua data tertinggi terletak di perairan Prigi sebesar 0,983. Dimana nilai korelasi tersebut termasuk dalam kategori sangat kuat untuk hubungan antar datanya. Sedangkan untuk nilai korelasi terendah terletak pada hubungan antar data di perairan Sadeng yaitu sebesar 0,517 . Hal ini diakibatkan untuk data pasang surut perairan Sadeng menggunakan data pasang surut dari BIG. Sedangkan untuk data pasang surut wilayah perairan Cilacap dan Prigi menggunakan data pasang surut global. 


\section{E. Analisa Nilai SLA dengan Volume Es di Kutub Selatan}

Dari pengamatan topografi es di kutub selatan menggunakan satelit Cryosat dilakukan pemodelan wilayah. Kemudian setelah itu dilakukan perhitungan volume es dari model yang didapatkan. Dimana hasil perubahan volume es tersebut akan dikaitkan dengan perubahan nilai SLA dengan menggunakan metode korelasi. Sehingga diharapkan dari analisa korelasi tersebut, ke dua data tersebut memiliki hubungan atau tidak. Berikut merupakan hasil analisa korelasi dari perubahan volume es dengan nilai SLA di perairan selatan Jawa.

Dari nilai korelasi antara nilai SLA dengan volume es di Kutub Selatan untuk wilayah perairan Cilacap sebesar 0,119, untuk wilayah perairan Sadeng sebesar 0,073, dan untuk wilayah perairan Prigi sebesar 0,067. Dari ketiga wilayah sampel perairan menunjukkan bahwa perubahan nilai sea level anomaly sangat kecil pengaruhnya dengan perubahan nilai volume es di kutub selatan. Secara keseluruhan untuk wilayah perairan selatan Jawa nilai korelasi yang didapat adalah 0,044. Sehingga dari hasil nilai korelasi menunjukkan sangat kecilnya pengaruh perubahan volume es terhadap perubahan muka air laut di perairan selatan Jawa. Hal ini dipengaruhi dengan posisi periaran Selatan pulau Jawa yang terletak jauh dari wilayah kutub selatan.

\section{F. Analisa Perubahan Muka Air Laut}

Analisis perubahan muka air laut menggunakan nilai regresi linear. Regresi linear adalah metode yang digunakan untuk membentuk model hubungan antara variabel terikat dengan satu atau lebih variabel bebas. Sehingga regresi mampu mendeskripsikan fenomena data melalui terbentuknya suatu model hubungan yang bersifat numerik.

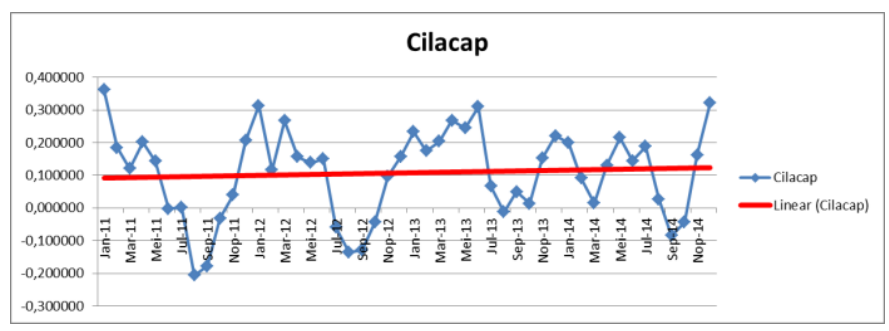

Gambar 11. Tren SLA Perairan Cilacap

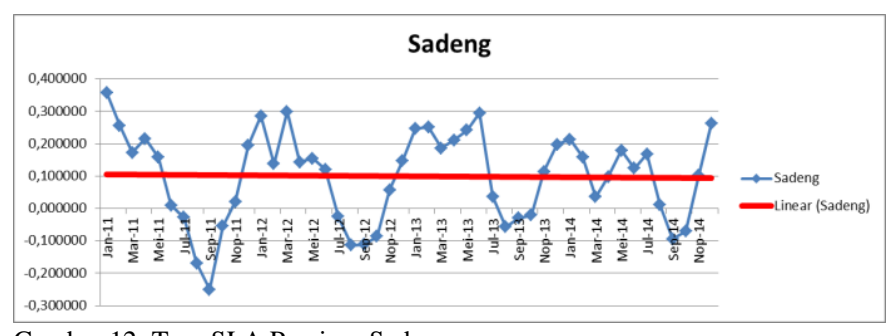

Gambar 12. Tren SLA Perairan Sadeng

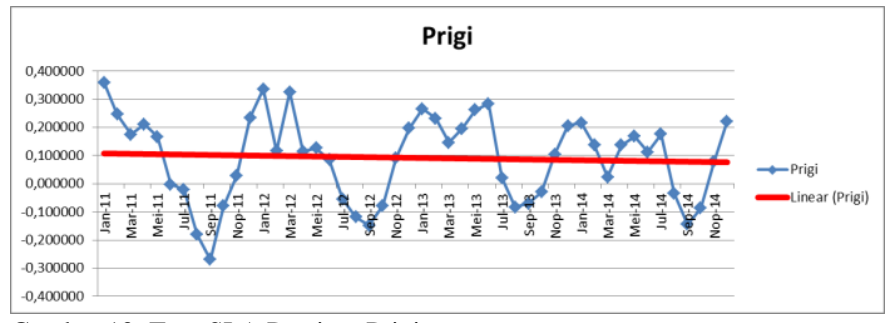

Gambar 13. Tren SLA Perairan Prigi

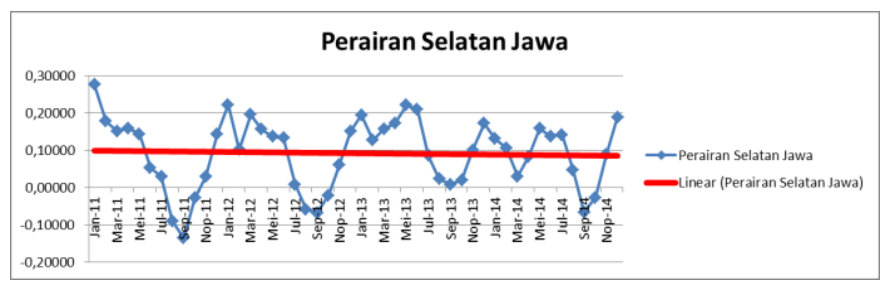

Gambar 14. Tren SLA Perairan Selatan Jawa

Dari grafik tersebut kemudian dicari tren kenaikan muka air laut setiap tahunnya dengan menggunakan persamaan garis linear yang diberikan sebagai berikut [7]:

$$
y=m x+c
$$

dimana nilai $m$ dan $c$ didapat dari :

$$
\begin{gathered}
\mathrm{m}=\frac{N \sum_{n=1}^{N} x_{n} y_{n}-\left(\sum_{n=1}^{N} x_{n}\right)\left(\sum_{n=1}^{N} y_{n}\right)}{N \sum_{n=1}^{N} x_{n}^{2}-\left(\sum_{n=1}^{N} x_{n}\right)} \\
\mathrm{c}=\frac{\sum_{n=1}^{N} y_{n}}{N}-m \frac{\sum_{n=1}^{N} x_{n}}{N}
\end{gathered}
$$

Dimana $y$ merupakan variabel dependen atau tak bebas yang dicari, dalam hal ini yaitu tren kenaikan muka air laut. $x$ merupakan variabel independen atau bebas yang menyatakan waktu, dalam hal ini yaitu jumlah bulan. m merupakan koefisien regresi yang menyatakan ukuran kemiringan garis (slope). Dan $c$ merupakan titik perpotongan garis dengan sumbu $Y$.

Dari perhitungan persamaan linear tersebut didapatkan hasil regresi dari masing masing perairan sebagai berikut :

- Perairan Cilacap : $y=0,00068 x+0,091043$

- Perairan Sadeng : $y=-0,00027 x+0,105579$

- Perairan Prigi : $y=-0,00027 x+0,105579$

- Perairan Perairan Selatan Jawa : $y=-0,00027 x+0,0991$

Selanjutnya mencari tren perubahan muka air laut dengan mencari nilai maksimal dan minimal dari masing masing hasil regresi. Dimana nilai maksimal dan minimal ini merupakan parameter waktu dari bulan ke-1 dan bulan ke-48.

Kemudian mencari tren kenaikan per tahun untuk setiap daerah pengamatan, nilai y maksimal dikurangi dengan nilai $y$ minimal dibagi dengan lamanya tahun pengamatan [8]. Berikut hasil tren perubahan muka air laut setiap wilayah perairan.

Tabel 7.

Nilai Tren Perubahan Setiap Perairan

\begin{tabular}{cc}
\hline \hline Nama Stasiun & Tren $(\mathrm{m} / \mathrm{th})$ \\
\hline Cilacap & 0,0079 \\
Sadeng & $-0,0032$ \\
\hline \hline
\end{tabular}




\begin{tabular}{cc}
\hline \hline Prigi & $-0,0082$ \\
Selatan Pulau Jawa & $-0,0032$ \\
\hline \hline
\end{tabular}

*tanda negatif $(-)$ menunjukkan bahwa tren perubahan muka laut mengalami penurunan setiap tahunnya.

Dari analisis tren perubahan muka air laut tersebut hanya terdapat satu perairan yang memiliki tren kenaikan yaitu perairan Cilacap. Sedangkan untuk keseluruhan wilayah perairan selatan pulau Jawa mengalami penurunan. Hal ini sejalan dengan tren dari nilai mean sea level dari pasang surut 3 stasiun pengamatan yang dijadikan sebagai validasi dari nilai SLA yang berasal dari data satelit Altimetri.

\section{G. Analisa Perubahan Volume Es di Kutub Selatan}

Analisa perubahan es di Kutub Selatan dilakukan dengan metode regresi linear. Dari metode ini akan didapatkan nilai tren perubahan volume es di Kutub Selatan setiap tahunnya.

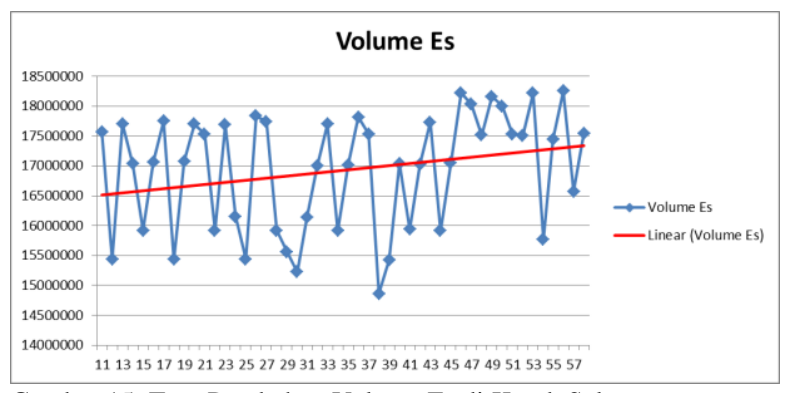

Gambar 15. Tren Perubahan Volume Es di Kutub Selatan

Untuk mencari tren perubahan volume es juga sama dengan mencari tren perubahan muka air laut dari nilai SLA. Sehingga dari persamaan (1) didapatkan model regresi linear perubahan volume es berikut $y=17537,839 x+16498132,53$. Dari persamaan regresi tersebut diketahui tren perubahan volume es setiap waktu bertambah. Dari persamaan di atas dicari nilai tren perubahan setiap tahun dengan cara pada mencari tren pada perubahan nilai SLA. Dari cara tersebut didapatkan tren perubahan volume sebesar $206.069 \mathrm{~m}^{3}$ setiap tahunnya.

Dari hasil tren perubahan volume es diketahui volume es di Kutub Selatan setiap tahun bertambah. Hal ini dikarenakan kawasan Antartika terdapat iklim serta arus laut yang berbeda dari sistem yang mempengaruhi Kutub Utara. Selain itu, suhu di Kutub Selatan lebih dingin dari pada Kutub Utara sehingga hal ini mendukung kondisi tidak melelehnya es di Kutub Selatan. Karena itulah dampak pemanasan global di Kutub Selatan tidak sekuat seperti yang melanda Kutub Utara. Sejauh ini dapat diamati, di Kutub Selatan relatif tidak terjadi pencairan lapisan es.

\section{KESIMPULAN DAN SARAN}

Adapun beberapa hal yang bisa disimpulkan dari penelitian ini adalah:

1. Nilai SLA tertinggi terjadi pada bulan Januari 2011, yaitu sebesar $0,27611 \mathrm{~m}$. Sedangkan untuk nilai SLA terendah terjadi pada bulan September 2011, yaitu sebesar -0,13596 m.

2. Volume es tertinggi pada kutub selatan terjadi pada bulan
Oktober 2014, yaitu sebesar $18.252 .379 \mathrm{~m}^{3}$. Sedangkan untuk nilai volume es terendah terjadi pada bulan Desember 2013, yaitu sebesar $14.859 .009 \mathrm{~m}^{3}$.

3. Nilai tren linear perubahan muka air laut di perairan selatan Jawa adalah sebesar $-3,2 \mathrm{~mm} / \mathrm{tahun}$

4. Nilai tren perubahan volume es di kutub selatan adalah sebesar $206.069 \mathrm{~m}^{3}$ setiap tahunnya.

5. Validasi data SLA dengan menggunakan data pasang surut dapat dilakukan karena korelasi antara nilai SLA data pasang surut lebih dari 0,5 hal ini menunjukkan hubungan dari kedua data kuat.

6. Dari data perubahan muka air laut sedikit sekali dipengaruhi oleh perubahan volume es di kutub selatan hal ini berdasarkan dari nilai korelasi antara data SLA di perairan selatan Jawa dengan volume es di Kutub Selatan 0,0444 yang termasuk dalam kriteria hubungan sangat lemah.

Berdasarkan penelitian ini, data satelit altimetri Jason-2 secara umum dapat digunakan untuk memantau fenomena kenaikan muka air laut. Namun diperlukan penelitian yang lebih intensif, terutama dalam hal lama pengamatan dan data pembanding lainnya seperti curah hujan. Sedangkan untuk data satelit Cryosat dapat digunakan untuk memantau perubahan topografi es karena memiliki lintang yang tinggi. Sehingga diperlukan penelitian yang lebih intensif, terutama dengan mengkombinasikan dengan es yang mengapung dilautan (sea ice), nilai gravitasi dari suatu tempat, dan data pembanding lainnya.

\section{DAFTAR PUSTAKA}

[1] IPCC. (2007). Climate Change 2007. Swedia: Intergovermental Panel On Climate Change.

[2] Hastho, W., Sorja, K., \& Yunianto, M. (2012). Analisa Sea Level Rise Data Satelit Altimetri Topex/Poseidon, Jason-1 dan Jason-2 di Perairan Laut Jawa Periode 2000 - 2010. Solo: FMIPA Universitas Sebelas Maret.

[3] Benada, J. R. (1997). User Handbook Physical Oceanography Ditributed Active Archive Center PO.DAAC Merged GDR (Topex/Poseidon). NOAA.

[4] AVISO. (2011). OSTM/Jason-2 Products Handbook. CNES, EUMETSAT, JPL, NOAA/NESDIS.

[5] Holgate, S. J., Matthews, A., Woodworth, L. P., Rickards, L. J., Tamisiea, M. E., Bradshaw, E., et al. (2016, April 18). Referencing the Tide Gauge Data Set. Retrieved 3 20, 2016, from Permanent Service for Mean Sea level: http://www.psmsl.org/data/obtaining

[6] Sudjana. (2002). Metode Statistika. Bandung: Trasito.

[7] Sarwono, J. (2006). Metode Penelitian Kuantitatif dan Kualitatif. Yogyakarta: Graha Ilmu.

[8] Dewantara, A. H. (2014). Analisa Luas Daerah Potensi Genangan Air Rob Akibat Kenaikan Muka Air Laut Menggunakan Data Satelit Altimetri. Surabaya: Prodi Teknik Geomatika-ITS. 